\title{
Effect of groundnut meal containing aflatoxin on Cynomolgus monkeys
}

\author{
By W. F. J. CUTHBERTSON, A. C. LAURSEN \\ AND D. A. H. PRATT \\ Glaxo Research Ltd, Greenford, Middx.
}

(Received 12 April 1967-Accepted 21 fune 1967)

\begin{abstract}
1. Both male and female Cynomolgus (Macaca irus) monkeys survived for 3 years without apparent ill health when fed on diets containing groundnut meal to provide up to $0.36 \mu \mathrm{g}$ aflatoxin $B_{1}$ per $g$ diet and thus supplying a mean daily consumption of up to $2 \mu \mathrm{g}$ aflatoxin $B_{1}$ per $\mathrm{kg}$ body-weight. No histological changes attributable to aflatoxicosis were discovered in any of the organs from the monkeys receiving these quantities of aflatoxin.

2. Few monkeys survived for more than a month or two when given a diet containing $\mathrm{I} .8 \mu \mathrm{g}$ aflatoxin $\mathrm{B}_{1}$ per $\mathrm{g}$, which provided about $5 \circ \mu \mathrm{g}$ aflatoxin $\mathrm{B}_{1}$ per $\mathrm{kg}$ body-weight per day. 3. No depression in growth rate nor effect on health was noted in those monkeys which survived on diets containing $\mathrm{I} \times 8 \mu \mathrm{g}$ aflatoxin $\mathrm{B}_{1}$, nor in any of the other monkeys.

4. Histological changes were observed in the livers of all monkeys receiving the diet containing $\mathrm{I}-8 \mu \mathrm{g}$ aflatoxin $\mathrm{B}_{1}$ per $\mathrm{g}$ for more than a month or two, but no abnormalities related to aflatoxicosis could be detected in any of the other organs, except for minor changes in the kidneys of two monkeys.

5. No tumours were seen in any of the monkeys, even in those surviving for 3 years on diets providing $\mathrm{I} \cdot 8 \mu \mathrm{g}$ aflatoxin $\mathrm{B}_{1} / \mathrm{g}$. Thus, no conclusions can be drawn from this work as to the carcinogenicity of aflatoxin in monkeys (still less in man), because the animals were young and little is known of the duration of exposure required to demonstrate carcinogenicity in this species.
\end{abstract}

Severe losses of young turkeys experienced in the United Kingdom in 1960 (Blount, I96I) were shown to be due to their diet containing groundnut meal with toxic properties. Other farm animals were shown by Loosemore \& Harding (1961) and by Loosemore \& Markson (I96I) to suffer similar toxic effects, ducklings (Asplin \& Carnaghan, 196r) being especially sensitive. A biological assay employing ducklings was soon developed by Sargeant, O'Kelly, Carnaghan \& Allcroft (I96r), and the toxicity of the affected batches of groundnut meal was then shown to be associated with the presence of a mould, Aspergillus flavus (Sargeant, Sheridan, O'Kelly \& Carnaghan 196I). Subsequently, several groups of workers (Van der Zijden, Koelensmid, Boldingh, Barrett, Ord \& Philp, r962; Nesbitt, O’Kelly, Sargeant \& Sheridan, 1962; de Iongh, Beerthuis, Vles, Barrett \& Ord, I962; Asao, Büchi, Abdel-Kader, Chang, Wick \& Wogan, 1963; Van Dorp, van der Zijden, Beerthuis, Sparreboom, Ord, De Jong \& Keuning, 1963; Hartley, Nesbitt \& O’Kelly, I963; Chang, Abdel Kader, Wick \& Wogan, 1963) showed that these toxic effects were brought about by a mixture of metabolites, all being difurano coumarin derivatives and formed by certain strains of $A$. flavus. The name 'aflatoxin' was given to this group of substances, the major components being designated aflatoxins $B_{1}, B_{2}, G_{1}$ and $G_{2}$.

Comparative feeding trials by Allcroft \& Carnaghan ( 1963 ) showed differences in susceptibility by different species. Lancaster, Jenkins \& Philp (1961) showed that, 
after about 6 months, hepatic tumours developed in rats given a diet containing $20 \%$ toxic groundnut meal, even though this animal appeared relatively resistant to the acutely toxic effects of aflatoxin. Hepatic tumours in the duckling (Carnaghan, 1965) have also been shown to follow administration of much lower levels of toxic groundnut meal for 14 months. Tulpule, Madhavan \& Gopalan (1964) showed that purified aflatoxin, at doses of $500 \mu \mathrm{g} / \mathrm{kg}$ body-weight per day, was rapidly fatal to monkeys, whereas lower doses $(25-250 \mu \mathrm{g} / \mathrm{kg}$ body-weight per day) did not produce apparent toxic effects within the 20-day test period.

Because of this potential carcinogenicity of toxic groundnut meal in one species, and because the groundnut is so important in human nutrition in many areas of the world, it was thought desirable to determine the toxicity of a contaminated sample of groundnut meal in a primate species, with special reference to the effects of long-term administration and possible hepato-carcinogenic effects.

It has been shown that the mixed aflatoxins will induce hepatic tumours in the rat (Barnes \& Butler, 1964), but, at the time the experiments reported here were planned (I96I-2), purified aflatoxins were not readily available, little was known of their stability or relative toxicity and it was uncertain whether they were the compounds responsible for the carcinogenic effects noted in the rat by Lancaster et al. (1961). A sample of highly toxic groundnut meal from the 'Rossetti' shipment (Allcroft \& Raymond, I966) was therefore used in this work. It was hoped that the concentration of toxic or carcinogenic agents could be estimated when methods were developed, and some assessment could ultimately be made of the toxicity of the active agents themselves.

In this series of tests, several different dietary concentrations of toxic groundnut meal were given for long periods, in order to determine whether the toxic groundnut meal could act as a carcinogen in the monkey and also to determine what levels would exert easily discernible toxic effects, as well as others that would not lead to any detectable reaction.

\section{EXPERIMENTAL}

\section{Monkeys}

Young Cynomolgus (Macaca irus) monkeys imported from Malaya were used. Their age was unknown, but the permanent medial incisors had erupted, though other permanent teeth were absent. This stage of dental development occurs at about 2 years of age in monkeys born in our colony; thus the initial age of the test monkeys was probably $2-3$ years.

The six animals (three male and three female) used in Expt I were selected from a batch kept with the other animals in the normal stock colony 60 days before the test began. The twenty animals used in Expt 2 were selected within a few days of arrival.

For 2 months, these monkeys were under observation, but no malarial or amoebic infections were detected. The animals were treated with piperazine citrate for worm infections (Strongyloides, Ascaridoidea and Trichiuris trichiura). Microfilaria were not detected in blood films, but all animals were given an injection of $\mathrm{x} \mathrm{ml} \mathrm{of} \mathrm{a} 20 \%(\mathrm{w} / \mathrm{w})$ 
solution of dimercaptosuccinate sodium salt to eliminate any microfilarial infection that might have existed. For 3 days, the monkeys were given a daily oral dose of $50 \mathrm{mg}$ chlortetracycline.

\section{Housing}

After selection, all monkeys were housed in steel wire cages $(6 \mathrm{I} \times 6 \mathrm{I} \times 74 \mathrm{~cm})$ in a separate laboratory throughout the tests, or as indicated in the text. All cages were equipped with food trays and water bottles.

Most of the animals in Expt 2 were housed as pairs until after 26 months, when some were separated because of their size, so that from this time onwards, all except nos. 8ro and $8 \mathrm{I} 5$ were individually housed.

\section{Groundnut meals}

The 'Rossetti' groundnut meal came from a 35 cwt sample that had been thoroughly mixed in a commercial feeding-stuffs mixer and packed in I cwt bags (Allcroft \& Raymond, I966). This batch was obtained from the 'Rossetti' shipment on which many of the original observations on aflatoxicosis had been made. It was found to contain only traces of aflatoxins other then aflatoxin $B_{1}$, and numerous assays have shown the content of aflatoxin $B_{1}$ to be close to $10 \mu \mathrm{g} / \mathrm{g}$ (Allcroft \& Raymond, 1966). No evidence has been found of any change in aflatoxin with age of the 'Rossetti' groundnut meal (Allcroft \& Raymond, 1966). The value of $10 \mu \mathrm{g}$ aflatoxin $\mathrm{B}_{1}$ per $\mathrm{g}$ 'Rossetti' groundnut meal has therefore been assumed for the work reported here.

Two 'non-toxic' batches of groundnut meal were provided. In one, aflatoxin could not be detected; in the other, used for the diets from September i 964 to September 1965, assays by the Tropical Products Institute showed the presence of between zero and $0.002 \mu \mathrm{g}$ aflatoxin per $\mathrm{g}$. During the feeding trials with monkeys a number of check assays were carried out at the Tropical Products Institute on the groundnut meals and on the other diets made from them. The results were found to be consistent with the value of $10 \mu \mathrm{g}$ aflatoxin $\mathrm{B}_{1}$ per $\mathrm{g}$ 'Rossetti' meal.

\section{Diets and management}

In Expt $\mathrm{I}$ the animals were allowed access to a mixture of diet I (Table $I$ ) and an equal weight of water for $2 \mathrm{~h}$ each morning, and to unrestricted supplies of grain mixture (approximately equal parts of whole maize, wheat and barley) each afternoon. All food was withdrawn from the cages at night. About Io g of orange or apple were provided per day. The monkeys rapidly adapted to these conditions and readily consumed up to $100 \mathrm{~g}$ diet I per day. After Io days, the quantities of diet I were restricted to 100,75 or $5^{\circ} \mathrm{g}$ per day, i.e. between 6 and $13 \mathrm{~g}$ 'Rossetti' meal per kg body-weight per day (Table 2).

In Expt 2, all animals were given diet 2 (Table 3) containing $18 \%$ 'aflatoxin-free' groundnut meal as the sole source of nourishment from Io to 23 August 1962, except for a daily slice of orange (about $10 \mathrm{~g}$ ) to provide ascorbic acid. Diet 2, and all other diets containing groundnut meal (Table 4), were presented as a paste made by mixing with an equal weight of tap water. Water was available in the cages at all times. On 
23 August 1962 the animals were allotted to the different treatment groups (Table 5), and thereafter were given one of the diets A, B, C or D (Table 4) each of which was the same as diet 2, except in the groundnut moiety. No other food was offered (apart from the ration of orange or apple), although for 2 months (27 December 1964 to ${ }_{24}$ February 1965) all were given, in error, one slice of white bread ( $\left.17 \mathrm{~g}\right)$ per day, which was eaten, and about $20 \mathrm{~g}$ of rat cubes of which only a small portion was consumed; these additions amounted to about $15-20 \%$ of the total food intake during this period.

All animals were weighed at intervals throughout the test and immediately before they were killed.

\section{Table I. Expt I. Composition of diet $\mathrm{I}$}

Basal mixture

\begin{tabular}{|c|c|}
\hline 'Rossettti' groundnut meal (\%) & $50 \cdot 0$ \\
\hline Maize meal $(\%)$ & 25.0 \\
\hline Sucrose $(\%)$ & $10 \cdot 0$ \\
\hline Fine millers offal $(\%)$ & $10 \cdot 0$ \\
\hline Molasses (\%) & $2 \cdot 5$ \\
\hline Ground limestone (\%) & $I \cdot 25$ \\
\hline Sodium chloride $(\%)$ & $I \cdot 25$ \\
\hline \multicolumn{2}{|c|}{ Mineral-vitamin mix (added at rate of $1 \mathrm{~g} / \mathrm{kg}$ ) } \\
\hline Vitamin $A^{*}$ & $I \times 10^{6}$ i.u. vitamin $A$ \\
\hline Vitamin $\mathrm{D}_{3}^{*}$ & $0.25 \times 10^{6}$ i.u. vitamin $\mathrm{D}_{3}$ \\
\hline Riboflavine & $400 \mathrm{mg}$ \\
\hline Pyridoxine hydrochloride & $100 \mathrm{mg}$ \\
\hline Cyanocobalamin & $400 \mu \mathrm{g}$ \\
\hline Nicotinic acid & $1000 \mathrm{mg}$ \\
\hline Saccharated ferrous carbonate & $15 \cdot 2 \mathrm{~g}$ \\
\hline Potassium iodate & $0.34 \mathrm{~g}$ \\
\hline Cupric carbonate & $2.0 \mathrm{~g}$ \\
\hline Manganous carbonate & $8 \cdot 4 \mathrm{~g}$ \\
\hline Cobalt oxide & $0.4 \mathrm{~g}$ \\
\hline Sodium molybdate $\left(\mathrm{Na}_{2} \mathrm{MoO}_{4} \cdot \mathrm{H}_{2} \mathrm{O}\right)$ & $0.4 \mathrm{~g}$ \\
\hline Maize meal to & $100 \mathrm{~g}$ \\
\hline
\end{tabular}

- Added as stabilized vitamins $A$ and $D_{3}$ preparation (Vitablend; Glaxo Laboratories Ltd, Greenford, Middlesex) containing 325000 i.u. vitamin A and 80000 i.u. vitamin $\mathrm{D}_{3}$ per $\mathrm{g}$.

\section{Dietary intakes}

In Expt I, consumption of diet I was measured throughout the test. Consumption was calculated, as dry weight of food eaten, from the difference between the amount offered and that uneaten during the ro-day period.

In Expt 2 the consumption of the diets A, B, C and D was determined from measurements of the weight of food offered and the weight of food spilt or uneaten during periods each of 7 days. The results obtained were not precise because the cages were not designed for metabolism experiments and it proved impossible to prevent contamination of spilt food and to separate it completely from urine and faeces; they therefore give only a rough indication of the amounts of food eaten. 
Vol. 2I

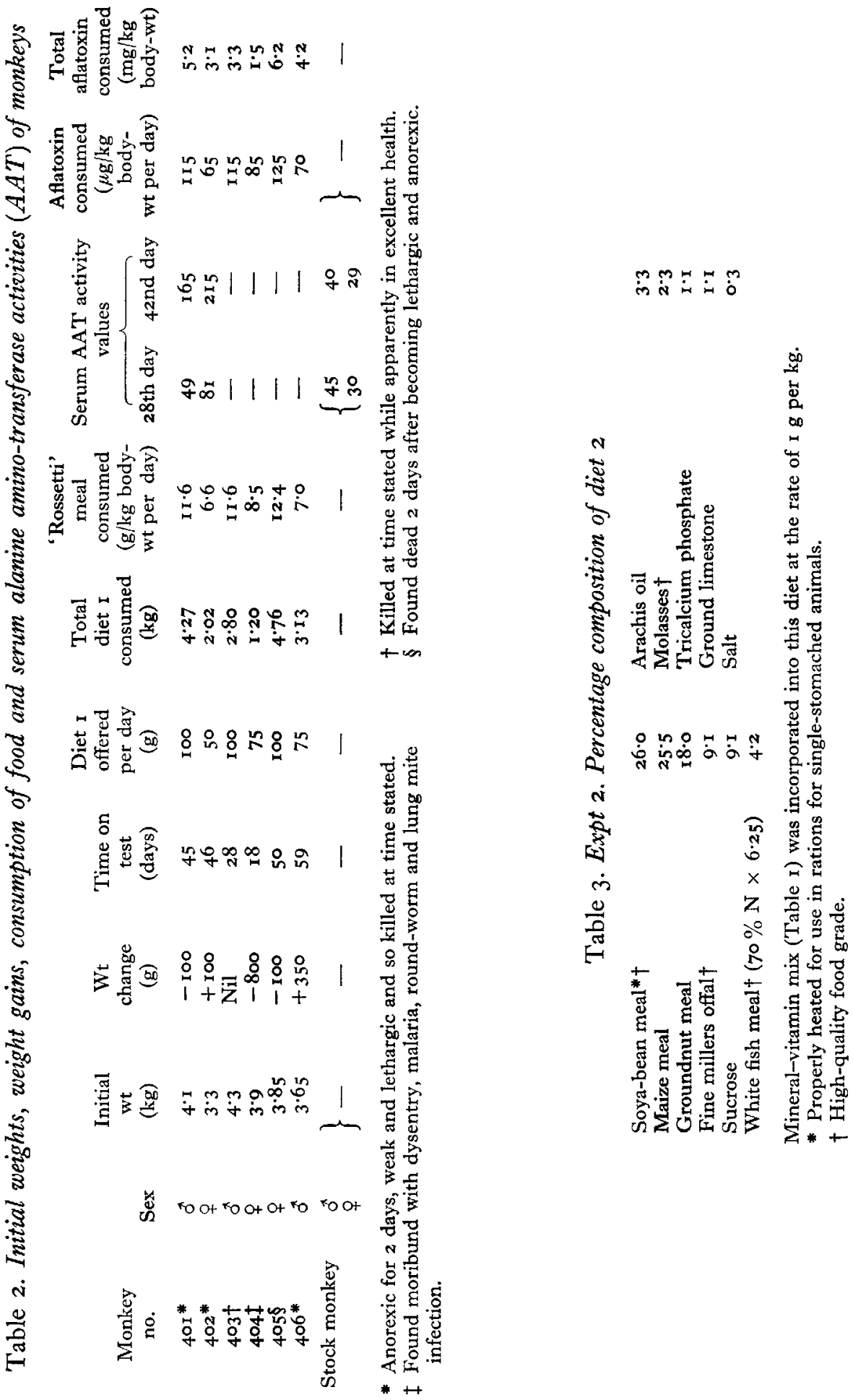




\section{Blood analyses}

Blood for analysis was removed by syringe from the femoral vein. Determinations of haemoglobin (as cyanmethaemoglobin), packed cell volume and total leucocyte count were made on each sample. Assays for other substances were done by the methods referred to, which, however, were adapted for use on the Auto Analyser.

Table 4. Levels of groundnut meal and aflatoxin in the diets

$\begin{array}{cccc}\text { 'Rossetti' } & \begin{array}{c}\text { Non-toxic } \\ \text { groundnut } \\ \text { meal }(\%)\end{array} & \begin{array}{c}\text { groundnut } \\ \text { meal }(\%)\end{array} & \begin{array}{c}\text { Calculated } \\ \text { aflatoxin } \\ \text { content }(\mu \mathrm{g} / \mathrm{g})\end{array} \\ \text { A } & 18.00 & 0.00 & \mathbf{1} \cdot 8 \\ \text { B } & 3.60 & 14.40 & 0.36 \\ \text { C } & 0.72 & 17.28 & 0.07 \\ \text { D } & 0.00 & 18.00 & 0.00 \\ \text { 'Rossetti' } & - & - & 10.0 \dagger \\ \text { meal } & - & - & 0.000-0.002 \ddagger \\ \text { Non-toxic } & - & & \end{array}$

* Diets A, B, C and D were made as shown in Table 3 and differed only in respect of the groundnut meal component, which totalled $18.0 \%$ in all instances.

$\dagger$ Allcroft \& Raymond (I966).

I Mean result of chemical determinations made by the Tropical Products Institute.

Table 5. Expt 2. Allocation of monkeys to cages and to treatment groups, with mean food consumptions

\begin{tabular}{|c|c|c|c|c|c|c|}
\hline \multirow[b]{2}{*}{ Diet } & \multirow[b]{2}{*}{ Cage } & \multirow{2}{*}{$\begin{array}{c}\text { Monkey } \\
\text { no. }\end{array}$} & \multirow[b]{2}{*}{ Sex } & \multicolumn{3}{|c|}{ Mean food consumption ( $\mathrm{g} / \mathrm{kg}$ body-wt day) } \\
\hline & & & & 15. viii. $62 *$ & $29 \cdot x \cdot 62 *$ & 29. iii. $65^{*}$ \\
\hline \multirow[t]{4}{*}{ A } & $\mathbf{D}$ & $\begin{array}{l}818 \\
819\end{array}$ & $\begin{array}{l}\text { q } \\
\text { q }\end{array}$ & $28 \dagger$ & $25 \dagger$ & 一 \\
\hline & $\mathrm{J}$ & $\begin{array}{l}830 \\
832\end{array}$ & $\begin{array}{l}\sigma \\
\sigma\end{array}$ & $25 t^{\dagger}$ & 8 & $(830) 25$ \\
\hline & $\mathrm{E}_{2}$ & 821 & 우 & 15 & - & - \\
\hline & I & $\begin{array}{l}836 \\
837\end{array}$ & $\begin{array}{l}0 \\
0\end{array}$ & $30 \dagger$ & $(837) 20$ & $(837) 20$ \\
\hline \multirow[t]{2}{*}{ B } & $\mathbf{C}$ & $\begin{array}{l}816 \\
817\end{array}$ & $\begin{array}{l}\text { p } \\
q\end{array}$ & $26 \dagger$ & $17 \dagger$ & - \\
\hline & $\mathbf{M}$ & $\begin{array}{l}828 \\
827\end{array}$ & $\hat{0}$ & $30 \dagger$ & $17 \dagger$ & $\begin{array}{l}(828) 28 \\
(827) 29\end{array}$ \\
\hline \multirow[t]{2}{*}{$\mathbf{C}$} & B & $\begin{array}{l}810 \\
815\end{array}$ & $\begin{array}{l}q \\
+ \\
q\end{array}$ & $30 \dagger$ & $22 \dagger$ & 32 \\
\hline & G & $\begin{array}{l}822 \\
824\end{array}$ & $\begin{array}{l}\hat{0} \\
\hat{0}\end{array}$ & $30 \dagger$ & $22 \dagger$ & $\begin{array}{l}(822) 36 \\
(824) 45\end{array}$ \\
\hline \multirow[t]{3}{*}{ D } & A & $\begin{array}{l}838 \\
839\end{array}$ & $\begin{array}{l}9 \\
9\end{array}$ & $25 \dagger$ & $27 \dagger$ & $(839) 44$ \\
\hline & $\mathbf{F}$ & $\begin{array}{l}823 \\
834\end{array}$ & $\begin{array}{l}\sigma \\
\sigma\end{array}$ & $29 \dagger$ & $25 \dagger$ & $\begin{array}{l}(823) 37 \\
(834) 39\end{array}$ \\
\hline & $\mathrm{E}_{1}$ & 812 & 우 & 30 & 28 & $812 \quad 48$ \\
\hline
\end{tabular}

- Commencement of measurements of food intake.

$\dagger$ Mean result for two animals in one cage. Number in parentheses denotes surviving animal of a pair of animals that were originally kept as pairs but separated before date stated. 
The methods used were: serum aspartate amino-transferase (L-aspartate 2-oxoglutarate amino-transferase E.C.2.6.r.I.) (Babson, Shapiro, Williams \& Phillips, I962); serum alanine amino-transferase (L-alanine: 2 -oxoglutarate amino-transferase E.C. 2.6.1.2.) (Reitman \& Frankel, I957); blood glucose (Hoffman, I937); urea nitrogen (Marsh, Fingerhut \& Kirsch, I957); inorganic phosphate (Fiske \& Subbarow, 1925); alkaline phosphatase (orthophosphoric monoester phospho-hydrolase; E.C.3.I.3.I.) (Powell \& Smith, I954); total protein (Weichselbaum, I946); bilirubin (Malloy \& Evelyn, I937); chloride (Zall, Fisher \& Garner, I956); calcium (Kessier \& Wolfman, 1964); and finally sodium and potassium, measured by flame photometry.

\section{Autopsy}

All animals were examined post mortem and organs were removed for histological examination when possible. The animals that were killed were first anaesthetized by an intravenous injection of a barbiturate. The abdomen was then opened to permit examination of the viscera, the livers were removed and the carcasses exsanguinated.

Tissues were fixed in $10 \%$ formalin with phosphate buffer added to $\mathrm{pH} 7{ }^{\circ}$, dehydrated in alcohol, cleared in chloroform and embedded in paraffin wax. Sections were cut at $5 \mu \mathrm{m}$ and stained with Harris's haematoxylin and eosin. Selective staining techniques used were McManus's periodic acid Schiff reaction, Schmorl's ferric chloride-potassium ferricyanide reaction, Gordon and Sweet's technique and Van Gieson's stain to demonstrate polysaccharides, lipofuscin, reticulin and collagen respectively. Frozen sections of heart, liver, kidney and adrenal glands were also stained with Oil Red $\mathrm{O}$ to demonstrate neutral fat. All the histological methods used in this investigation are according to Culling (I957).

\section{RESULTS \\ $\operatorname{Expt} \mathrm{I}$}

Table 2 gives the identification numbers, the initial weights and weight gains or losses of the animals during the test period, together with the time they remained on test before death. The results of serum alanine amino-transferase assays carried out after 28 and 42 days on two of these monkeys and on two of similar weight from the stock colony are also given.

One monkey (403) was killed after 28 days on test; another was found dead and the rest were killed when they became ill.

\section{Gross observations at autopsy}

All animals appeared well-nourished and hydrated at autopsy, except no. 404 which was thin and dehydrated, with sunken eyes and hind-quarters soiled with faeces.

With the exception to be noted, the thoracic and abdominal organs and trachea, larynx, thyroid and testes or ovaries of all animals appeared normal.

Fine round-worms (species not identified) about $5 \mathrm{~cm}$ long were found in the stomach, pleural and peritoneal cavities of monkey no. 404 .

The cut surface of the liver of monkey no. 405 was somewhat friable, but this organ 
appeared normal in all the other monkeys. The mesentery was inflamed without obvious cause in monkey no. 402. Enlargement of lymph nodes (axillary, inguinal and mesenteric nodes equally involved) was noted in monkey no. 406, and, in monkey no. 405, dark purple patches were observed on the spleen.

\section{Histological findings}

The livers of monkeys nos. 403 and 404 were essentially normal. There was no evidence of bile duct proliferation or degeneration of the parenchymal cells, although in monkey no. 404 there was a small granulomatous lesion around a dead nematode.

The livers of nos. $401,402,405$ and 406 had a similar appearance with large oval or spindle-shaped basophilic cells that had proliferated to form cords or acini deep in the liver parenchyma. Often these had surrounded and apparently isolated groups of liver cells. The selective stains indicated that the proliferating cells were most probably bile-duct epithelium. In no. 405, liver cell necrosis had occurred around the portal tracts and many of the macrophages in the inflammatory exudate contained lipofuscin granules. There was evidence of chronic inflammation, the connective tissue supporting some ducts containing many lymphocytes and plasma cells. Most of the large bile ducts appeared to be entirely normal.

Branches of the portal vein were infiltrated by acute inflammatory cells; it is not known whether this was a reaction to nearby liver cell necrosis or caused by toxic damage to the vessel wall. Selective staining with Oil Red O demonstrated the presence of quantities of free fat in the parenchymal liver cells of monkeys nos. 40I, 402,405 and 406, all zones being affected. The histological changes were greatest in monkey no. 405 which had died, and in monkey no. 406, which had survived for the longest period.

Terminal degenerative changes were present in the heart muscle from three animals (nos. 40I, 402 and 405), whereas the sections of kidney, lung, spleen, gonad, pancreas, gastro-intestinal tract, adrenal and thyroid were essentially normal.

\section{Expt 2}

The monkeys rapidly adapted to the conditions of housing and management and consumed the diets offered. Anorexia developed during the period immediately before death in those animals that died or were killed before the end of the test.

The animals were weighed at intervals throughout the observation period and the number of days they were on test before they died or were killed was recorded (Table 6).

The approximate dietary intake of the animals was determined on three occasions (Table 5).

Serum aspartate amino-transferase and serum alanine amino-transferase activities were determined after the animals had been on test for $\mathrm{I}$ month and also shortly before the termination of the experiments (Table 7).

Cytological and chemical examinations of femoral venous blood samples, withdrawn on I6 February and ro August 1965 , failed to reveal any significant differences between the treatment groups. 
Table 6. Expt 2. Weight and survival time of each monkey

\begin{tabular}{|c|c|c|c|c|c|}
\hline Diet & $\begin{array}{c}\text { Monkey } \\
\text { no. }\end{array}$ & Sex & $\begin{array}{c}\text { Initial wt } \\
(\mathrm{g})\end{array}$ & $\begin{array}{c}\text { Final wt } \\
(\mathrm{g})\end{array}$ & $\begin{array}{l}\text { Duration of } \\
\text { test (days) }\end{array}$ \\
\hline \multirow[t]{7}{*}{ A } & 818 & q & 1125 & 1350 & 103 \\
\hline & 819 & 우 & 1025 & 1250 & 77 \\
\hline & 830 & 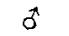 & $125^{\circ}$ & 4100 & 1123 \\
\hline & 832 & o & 1825 & 1600 & 73 \\
\hline & 821 & 車 & 1600 & I 600 & $4^{8}$ \\
\hline & 836 & $\sigma^{*}$ & 1250 & 1600 & 29 \\
\hline & 837 & 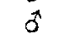 & 1700 & 5900 & I 123 \\
\hline \multirow[t]{4}{*}{ B } & $8 I 6$ & 우 & 1250 & 1925 & 296 \\
\hline & 817 & 우 & I350 & 2500 & 709 \\
\hline & 828 & $\delta$ & $125^{\circ}$ & $43^{2} 5$ & I I 23 \\
\hline & 827 & $\sigma$ & $125^{\circ}$ & 5125 & I I 23 \\
\hline \multirow[t]{4}{*}{ C } & 810 & 우 & I $35^{\circ}$ & 3400 & I I 23 \\
\hline & 8 I $5_{5}$ & ㅇ & $I 35^{\circ}$ & 4100 & $\operatorname{II23}$ \\
\hline & 822 & $\partial$ & 1125 & 4325 & 1123 \\
\hline & 824 & 0 & 1350 & 5450 & I 123 \\
\hline \multirow[t]{5}{*}{$\mathrm{D}$} & 838 & 우 & $125^{\circ}$ & 1825 & I 88 \\
\hline & 839 & q & I $35^{\circ}$ & 2950 & I I 23 \\
\hline & 823 & $\delta$ & II 50 & 3075 & 1123 \\
\hline & 834 & $d$ & $135^{\circ}$ & 6025 & 1123 \\
\hline & 812 & 우 & $135^{\circ}$ & 2500 & I 123 \\
\hline
\end{tabular}

* Recorded on ro August 1962, 13 days before the start of the test period.

Table 7. Aspartate amino-transferase (L-aspartate 2-oxoglutarate amino-transferase; EC 2.6.I.I.) and alanine amino-transferase (L-aspartate 2-oxoglutarate amino-transferase; EC 2.6.1.2.) activities of the serum of monkeys

\begin{tabular}{|c|c|c|c|c|c|c|c|}
\hline \multirow[b]{2}{*}{ Group } & \multirow{2}{*}{$\begin{array}{l}\text { Monkey } \\
\text { no. }\end{array}$} & \multirow[b]{2}{*}{ Sex } & \multicolumn{3}{|c|}{$\begin{array}{c}\text { EC 2.6.I.I } \\
\text { (units } / \mathrm{ml} \text { serum) }\end{array}$} & \multicolumn{2}{|c|}{$\begin{array}{c}\mathrm{EC}_{2.6 .1 .2} \\
\text { (units } / \mathrm{ml} \text { serum) }\end{array}$} \\
\hline & & & 10. $x .65$ & I6. ii. $6_{5}$ & Io. viii. 65 & I6. ii. 65 & Io. viii. \\
\hline \multirow[t]{7}{*}{$\mathbf{A}$} & 818 & 웅 & 40 & - & - & - & - \\
\hline & 819 & $\phi$ & $>90$ & - & - & - & - \\
\hline & 830 & 0 & 78 & 37 & 428 & 40 & 25 \\
\hline & 832 & $\hat{\sigma}$ & 70 & - & - & - & - \\
\hline & 821 & 우 & 78 & 一 & - & - & - \\
\hline & 836 & $\delta$ & - & - & - & - & - \\
\hline & 837 & $\sigma^{*}$ & 33 & 44 & 70 & 23 & I 2 \\
\hline \multirow[t]{4}{*}{ B } & $8 \mathrm{I} 6$ & 우 & $4 x$ & - & - & - & - \\
\hline & 8 I 7 & 9 & 53 & - & - & - & - \\
\hline & 828 & $\hat{O}$ & 62 & $2 I$ & 90 & 8 & Io \\
\hline & 827 & s & 64 & $2 I$ & 70 & 6 & II \\
\hline \multirow[t]{4}{*}{$\mathrm{C}$} & 810 & 움 & 35 & 25 & 20 & 5 & 9 \\
\hline & $8{ }_{5}$ & 운 & 43 & 22 & - & I5 & 5 \\
\hline & 822 & $\hat{0}$ & 30 & 29 & I 54 & 9 & 12 \\
\hline & 824 & $\hat{\sigma}$ & 45 & 24 & 52 & 9 & IO \\
\hline \multirow[t]{5}{*}{$\mathbf{D}$} & $8_{3} 8$ & q & 25 & - & - & 一 & 一 \\
\hline & 839 & 우 & 30 & 26 & 75 & 17 & 8 \\
\hline & 823 & o & $3^{8}$ & 32 & 75 & 20 & 8 \\
\hline & 834 & $\sigma^{x}$ & 65 & 26 & I 28 & 25 & 9 \\
\hline & $8 \mathrm{I2}$ & q & 73 & 30 & 58 & 12 & 8 \\
\hline
\end{tabular}

Enzyme activities expressed in units as described for EC 2.6.I.I. by Babson et al. (1962) or by Reitman \& Frankel (1957) for EC 2.6.1.2. 
Histological examinations were made of tissues from all monkeys killed at the end of the test and on all but one (no. ${ }_{3} 6$ ) of the animals that had died during the course of the experiment.

\section{Mortality}

Eight of the twenty monkeys died or were killed before the end of the experiment. The circumstances of the deaths were as follows:

Group $A$ (I.8 ppm aflatoxin). This group comprised four males and three females: five of these animals died or were killed before the end of the experiment. One animal (a male, 836 ) died suddenly after 29 days; the other four became listless and anorexic 2 or 3 days before being killed (females 821,819 and 818 after 48,77 and 103 days respectively) or before dying (male 832 after 73 days).

Group $B$ (0.36 ppm aflatoxin). This group comprised two males and two females; both females died before the end of the experiment. One (816) died suddenly after 42 weeks; the other $(8 \mathrm{i} 7)$ hanged itself by its neck chain after being on test for 2 years.

Group $C(0.07 \mathrm{ppm}$ aflatoxin). This group comprised two males and two females, none of which died before the end of the experiment.

Group D (no aflatoxin). This group comprised two males and three females; one of the females $(838)$ died of dysentery 27 weeks after the start of the tests.

The other twelve monkeys (two in group A, two in group B, four in group $\mathrm{C}$ and four in group D) were killed after receiving the test diet for 37 months.

\section{Post-mortem and histological observations}

The twenty animals appeared to be well-nourished and had healthy fur; there were no clinical signs of jaundice or anaemia. There were no effusions in the pleural, pericardial or peritoneal cavities.

The heart, trachea, lungs, kidneys, bladder, gonads, uterus, prostate, thyroid, adrenal, tongue, oesophagus, larynx, stomach, salivary glands, pancreas and brain appeared normal. Although the thymus was sought for in each animal, in only four were the samples found to contain thymic tissue on histological examination; it appeared normal in all instances. No significant differences were detected between the weights (as \% of body-weight) of the major organs (heart, lung, liver, kidney, gonads, spleen, thyroid and brain) from the animals in the different treatment groups. For convenience, animals that died during the test have been considered separately from those surviving for the 3-year test period.

Animals dying or killed during the test. In three animals $(818,821$ and 832$)$ in group A, the liver appeared paler than usual and somewhat swollen. In another animal $(838$, group D) the mucosa of the lower third of the small intestine and upper part of the colon was ulcerated and contained blood and mucus in the intestinal contents. Shigella flexneri was isolated from the gut.

Tissues from one monkey ( 836 in group A) were not suitable for detailed microscopic examination because the corpse had been deep-frozen.

There was marked liver cell damage in monkeys 818,821 and 832 , from group A. Central zonal liver cell necrosis or degeneration was accompanied by liver cell 
regeneration and bile duct and fibroblastic proliferation; some degree of fatty change was evident in all these livers and also in no. 8I9 (group A) in which proliferative changes were not observable. Livers from nos. 838 (group D) and 816 and 817 (group B) appeared normal.

The lower third of the small intestine from one of the animals $\left(8_{3} 8\right)$ was acutely inflamed after $S$. flexneri infection. Some renal tubular atrophy was present in monkeys 8I9 and 82I (group A), but the sections of kidneys from the other animals appeared normal. Lung, ovaries, spleen, bone marrow, prostate, uterus, pituitary, adrenal, thyroid and brain tissues also appeared normal.

Animals surviving for 3 years. In animal 830 (group A), the liver had the appearance typical of early coarse nodular cirrhosis. The livers of all others appeared normal. A tapeworm (Anoplocephalidea sp.) was found in the lumen of the small intestine of monkey no. 823 .

The liver of monkey no. 830 (group A) contained nodules of liver cells ranging from $5 \mathrm{~mm}$ to less than $\mathrm{I} \mathrm{mm}$ in diameter: these were supported by a very cellular fibrous and ductular tissue. Many of the nodules were composed of liver cells arranged in an essentially normal architecture, but others comprised clusters of liver cells arranged irregularly. Free lipid was present in a few cells, especially in those from the nodules of more irregular pattern. The cells towards the centre of the nodules often appeared normal, whereas those towards the periphery were frequently bizarre, appearing as enlarged cells with macronuclei, prominent eosinophilic nucleoli and quantities of lipofuscin. The liver from the other survivor in group A (837) had normal architecture, but with certain cytological features indicative of cell damage. Binucleate liver cells were common and a number of large cells with macronuclei were present. There was no indication of bile duct proliferation of fibrosis. All other livers appeared normal and a detailed comparison of the livers from the animals in groups B, C and D failed to reveal any histological differences between them.

Apart from one animal ( $8 \mathrm{I}_{5}$ ), in which the bladder showed changes of mild chronic cystitis, no abnormalities were seen in heart, kidney, bladder, spleen, bone marrow, prostate, uterus, pituitary, adrenal, thyroid, thymus, brain or gonads.

\section{DISCUSSION}

\section{Mortality}

The results of Expt I (Table 2) showed that an intake of aflatoxin $B_{1}$ of more than $65 \mu \mathrm{g} / \mathrm{kg}$ body-weight per day is lethal to both male and female monkeys within I or 2 months, and that death occurs after ingestion of between 3 and $6.5 \mathrm{mg}$ aflatoxin.

Table 8 summarizes the incidence of deaths noted during the 3 -year test period in Expt 2. Female monkeys may be more susceptible to aflatoxicosis than males, in that all three females in group A died, whereas two of the four males survived. Further work is necessary to confirm this observation. By contrast, the male rat is more susceptible than the female (Butler, I964). The monkeys dying from aflatoxicosis tended to do so within a few months of being given the diets containing the 'Rossetti groundnut meal. A diet containing $\mathrm{r} 8 \%$ 'Rossetti' meal ( $\mathrm{I} .8 \mu \mathrm{g}$ aflatoxin/g diet) 
killed more female than male monkeys. All the male monkeys receiving $3.5 \%$ of 'Rossetti' meal ( $0.35 \mu \mathrm{g}$ aflatoxin/g diet) survived. The death of one female $(817)$ was certainly not attributable to aflatoxicosis and no clear signs of it were found in the other female (8I6) that died.

Table 8. Expt 2. Incidence of deaths and survival time of the monkeys during the 3-year observation period

\begin{tabular}{|c|c|c|c|c|c|}
\hline \multirow[b]{2}{*}{ Group } & \multirow[b]{2}{*}{$\begin{array}{c}\text { Monkey } \\
\text { no. }\end{array}$} & & \multicolumn{2}{|c|}{ No. of days surviving before } & \multirow[b]{2}{*}{$\begin{array}{l}\text { Total no. } \\
\text { of deaths* }\end{array}$} \\
\hline & & Sex & $\begin{array}{l}\text { Death probably } \\
\text { attributable to } \\
\text { aflatoxicosis }\end{array}$ & $\begin{array}{l}\text { Death not directly } \\
\text { attributable to } \\
\text { aflatoxicosis }\end{array}$ & \\
\hline \multirow[t]{4}{*}{ A } & $\begin{array}{l}818 \\
819 \\
821\end{array}$ & $\begin{array}{l}0 \\
q \\
+ \\
0 \\
q\end{array}$ & $\begin{array}{r}103 \\
77 \\
48\end{array}$ & $=$ & $\{3$ \\
\hline & 830 & 0 & - & - & 1 \\
\hline & $\begin{array}{l}832 \\
836\end{array}$ & 0 & $\begin{array}{l}73 \\
29\end{array}$ & $\bar{z}$ & 2 \\
\hline & 837 & $\hat{o}$ & - & - & \\
\hline \multirow[t]{3}{*}{ B } & $\begin{array}{l}816 \\
817\end{array}$ & $\begin{array}{l}q \\
q\end{array}$ & $\overline{-}$ & $\begin{array}{l}296 \\
700\end{array}$ & $\{2$ \\
\hline & 828 & o & - & - & do \\
\hline & 827 & $\hat{\sigma}^{2}$ & - & - & $\{0$ \\
\hline \multirow[t]{3}{*}{$\mathrm{C}$} & 810 & $\frac{1}{1}$ & - & - & \{o \\
\hline & 822 & \% & - & - & 10 \\
\hline & 824 & 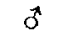 & - & - & $1^{\circ}$ \\
\hline \multirow[t]{4}{*}{ D } & 838 & q & - & 188 & \\
\hline & $\begin{array}{l}839 \\
812\end{array}$ & $\begin{array}{l}9 \\
0 \\
0\end{array}$ & $=$ & $=$ & $\{1$ \\
\hline & $82_{3}$ & $a^{*}$ & _- & - & \\
\hline & 834 & o & - & - & $\{0$ \\
\hline
\end{tabular}

* Survivors were killed II 23 days after the start of the experiment.

\section{Aflatoxin consumption}

Only rough estimates may be made of the total food consumed by the animals in Expt 2 (Table 5), but if the animals are assumed to have eaten an average of $25-30 \mathrm{~g}$ diet $/ \mathrm{kg}$ body-wight per day over the whole test period, then the amounts of aflatoxin ingested per animal were as shown in Table 9.

The results noted in Table 9 suggest that all female and about $50 \%$ of male monkeys consuming about $50 \mu \mathrm{g}$ aflatoxin per $\mathrm{kg}$ body-weight per day may die after consuming about 2.5-10 mg aflatoxin, but it is possible that they could survive indefinitely at an intake of $10 \mu \mathrm{g} / \mathrm{kg}$ body-weight per day. One female (8I7) given this amount did in fact survive for 2 years before accidental death removed her from the experiment. The other female monkey $(816)$ given this level of toxic meal survived for 10 months and died without any signs of aflatoxicosis, which would have been expected at this time had this monkey reacted to aflatoxin in the same way as all the others exposed to higher concentrations of the toxin for more than a few weeks in Expts $\mathrm{I}$ and 2. 
Both male and female monkeys may survive for at least 3 years with intakes of about $2 \mu \mathrm{g}$ aflatoxin $/ \mathrm{kg}$ body-weight per day. Few monkeys survived administration of about $50 \mu \mathrm{g}$ aflatoxin $/ \mathrm{kg}$ body-weight per day; this observation is in agreement with those from Expt I (Table 2), which show that dietary intakes of over $65 \mu \mathrm{g}$ aflatoxin $/ \mathrm{kg}$ body-weight per day were fatal within I to 2 months.

These findings are also in general agreement with those of Tulpule et al. (1964), who found that daily administration of a purified aflatoxin preparation at the rate of $500 \mu \mathrm{g}$ or more per $\mathrm{kg}$ body-weight was rapidly lethal to young Rhesus monkeys whereas doses of $25-250 \mu \mathrm{g} / \mathrm{kg}$ per day, i.e. doses similar to those employed in Expt I, did not induce the apparent ill effects within about 20 days. In our experiments no unequivocal signs of aflatoxicosis were noted in the two monkeys 403 and 404 killed I8-28 days after consuming 85-I I $5 \mu \mathrm{g}$ aflatoxin $/ \mathrm{kg}$ per day. On the other hand, signs of aflatoxicosis were invariably noted in all animals exposed to about $50 \mu \mathrm{g}$ aflatoxin $/ \mathrm{kg}$ per day for more than 45 days.

Table 9. Expt 2. Aflatoxin consumption of the monkeys during the 3-year test period

\begin{tabular}{|c|c|c|c|c|c|}
\hline \multirow[b]{3}{*}{ Group } & \multicolumn{4}{|c|}{ Total aflatoxin (approx.) consumed (mg) } & \multirow{3}{*}{$\begin{array}{l}\text { Mean aflatoxin intake } \\
\text { ( } \mu \mathrm{g} / \mathrm{kg} \text { body-wt day) }\end{array}$} \\
\hline & \multicolumn{2}{|c|}{ Survivors } & \multicolumn{2}{|c|}{ Non survivors } & \\
\hline & q & s & q & 0 & \\
\hline A & - & 50 & $2 \cdot 5-10$ & $I \cdot 5-5 \cdot 0$ & 50 \\
\hline B & 一 & I0 & $2 \cdot 5-7 \cdot 5$ & - & 10 \\
\hline C & 2 & 2 & - & - & 2 \\
\hline D & $0.0-0.01$ & $0.0-0.01$ & - & 一 & $0.00-0.01$ \\
\hline
\end{tabular}

\section{Histological observations}

In Expt I liver damage was not apparent in the two animals (403 and 404) examined after receiving aflatoxin for less than 30 days. On the other hand, it was clearly discernible in the four animals that survived for more than 45 days. The two animals without liver damage were consuming as much aflatoxin each day as those in which it later developed. It may thus be concluded that the poison is cumulative since the duration of exposure is important in determining the degree of liver damage.

In Expt 2, histological changes were noted in all six of the livers examined from the seven animals receiving the diet with the highest level (18\%) of 'Rossetti' meal and containing $\mathrm{r} \cdot 8 \mu \mathrm{g}$ aflatoxin/g. The degree of liver damage differed somewhat from one animal to another. No abnormalities could be seen in the liver from monkeys in any of the other groups.

No evidence of tumours was seen in the livers of the monkeys surviving for 3 years on the highest level of aflatoxin.

Prolonged administration of high dietary levels of 'Rossetti' meal supplying $5^{\circ} \mu \mathrm{g}$ aflatoxin or more per kg body-weight per day may have affected the kidney; atrophic changes were noted in the kidneys of two of the animals in Expt $I$ and in two of those given $18 \%$ 'Rossetti' meal in Expt 2. 
A number of other abnormalities were noted, but none appeared to be related to the ingestion of 'Rossetti' meal.

From these observations it may be concluded that prolonged administration of more than $3.6 \%$ dietary 'Rossetti' meal (ro $\mathrm{g}$ aflatoxin $/ \mathrm{kg}$ body-weight per day) is necessary to induce histologically detectable changes in the liver of the monkey and that the administration of $18 \%$ or more dietary 'Rossetti' meal ( $50 \mu \mathrm{g}$ or more aflatoxin per $\mathrm{kg}$ body-weight per day) leads to changes in the histological appearance of the liver and possibly of the kidney.

These observations are in broad agreement with those of Tulpule et al. (1964), who used Rhesus monkeus dosed with a purified aflatoxin preparation for periods of up to 28 days, and observed marked liver and minor kidney changes.

\section{Growth rates}

The results presented in Table 6 show that administration of dietary 'Rossetti' groundnut meal did not significantly affect the weight gains of the monkeys. The animals on the control diet continued to gain weight throughout the test. It is not possible to say whether the basal diet was completely satisfactory for monkeys, but no signs of nutritional deficiency or of disinclination to consume the diet were noticed during the test. It is thus considered that the diets were not deficient in any major respect.

\section{Blood examinations}

The results presented in Tables 2 and 7 show that in general the serum activities of both aspartate amino-transferase and alanine amino-transferase tended to be elevated in the groups receiving the highest level of toxic groundnut meal. This would be expected if the presence of both these enzymes in the serum is an indication of liver damage. However, at no time were the changes statistically significant $(P=0.05)$.

A number of blood and serum tests were carried out on two occasions during the last 6 months of the test period. On neither of these occasions could material differences be noted between any of the test groups except that in one instance serum bilirubin levels were on average rather higher in those monkeys given diets A and $B$ (i.e. those diets with the larger levels of toxic groundnut meal), as would perhaps be expected if liver damage was more common in these groups. This effect was not clearly detectable when the same test was repeated. On one occasion, some monkeys in the control group were found to have lower serum inorganic phosphate levels than the others. It is not known what significance, if any, may be attached to this observation.

Tulpule et al. (1964) showed in their tests that administation of aflatoxin leads to marked changes in serum constituents indicative of gross liver damage. Such marked changes were not noted in our tests, probably because of the less acute conditions used.

\section{General conclusions}

The Cynomolgus monkey reacts like the guinea-pig, rather than like the rat, to diets containing high levels of aflatoxin. The monkeys survive only a few weeks on 
such diets and die with extensive liver damage. Rats survive on diets containing aflatoxin at least up to a level of $4 \mu \mathrm{g} / \mathrm{g}$, but develop liver tumours after $30-40$ weeks (Butler \& Barnes, I963).

The experiments described have shown that there is a fairly sharp dividing line between the doses of aflatoxin that produced marked histological liver changes and a dose that produced no detectable histological changes, even after 3 years continual exposure. Although it seems improbable that the monkeys on these lower doses (diets B and C) would have developed liver cell changes after an even longer exposure, we cannot be certain of this. It is unfortunately impossible to draw any conclusions from these experiments about the carcinogenic action of aflatoxin on monkeys.

It has proved very difficult to produce liver tumours in guinea-pigs given a diet containing aflatoxin for up to 3 years, but liver cirrhosis and some liver cell changes can be produced in animals that are able to survive the acute toxic effects of high dietary levels of aflatoxin (J. M. Barnes \& W. H. Butler, private communication). Monkeys seem to react in a similar way.

No tumours were seen in the livers of the monkeys surviving for 3 years on the highest level ( $\mathrm{r} \cdot 8 \mu \mathrm{g} / \mathrm{g}$ diet) of aflatoxin. However, it should be emphasized that these monkeys were young and even at the end of the experiments many of them were still sexually immature. At present, there is little evidence on the susceptibility of monkeys to liver carcinogens or of the duration of exposure that must precede the onset of liver cancer. An exception is the powerful liver carcinogen, diethyl nitrosamine, which has induced tumours in monkeys dosed from birth (Kelly, O'Gara, Adamson, Gadekar, Botkin, Reefe \& Kerber, I966).

Because so little is known about the response of monkeys to chemical carcinogens, it is not possible to draw any conclusions from these experiments about the susceptibility of man to the toxic or carcinogenic action of aflatoxin.

The fact that species seem to differ widely in their sensitivity to this fungal toxin underlines the desirability of trying to measure how far people are actively exposed to aflatoxin to see if this can be correlated with any unusual incidence of disease among the more heavily exposed groups.

The authors thank Mr D. P. Wright (Glaxo Research Ltd, Sefton Park) for the feeding and management of the monkeys during these experiments, Dr C. S. Heyman (Glaxo Research Ltd, Sefton Park) for selection of the animals used in Expt I, Miss H. M. Sharpe and Mr J. D. Caisey (Toxicology Department, Glaxo Research Ltd) for the analyses of blood and serum. Our thanks are also expressed to Dr R. Allcroft (Central Veterinary Investigation Laboratories, Weybridge) and Dr W. D. Raymond (Tropical Products Institute, London) for help in the preparation of the paper and to the Central Veterinary Investigation Laboratory for generous supplies of the groundnut meal.

We gratefully acknowledge the assistance of Dr J. M. Barnes (Toxicology Research Unit, MRC Laboratories, Surrey) in the interpretation of the histological findings and in the presentation of this work. 


\section{REFERENCES}

Allcroft, R. \& Carnaghan, R. B. A. (1963). Chemy Ind. p. 50.

Allcroft, R. \& Raymond, W. D. (1966). Vet. Rec. 79, 122.

Asao, T., Büchi, G., Abdel-Kader, M. M., Chang, S. B., Wick, E. L. \& Wogan, G. N. (1963). f. Am. chem. Soc. 85, 1706 .

Asplin, F. D. \& Carnaghan, R. B. A. (196r). Vet. Rec. 73, 1215.

Babson, A. L., Shapiro, P. O., Williams, P. A. R. \& Phillips, G. E. (1962). Clinica chim. Acta 7, 199.

Barnes, J. M. \& Butler, W. H. (1964). Nature, Lond. 202, 1016.

Blount, W. P. (1961). Turkeys 9, 52.

Butler, W. H. (1964). Br. . Cancer $\mathbf{1 8}, 756$.

Butler, W. H. \& Barnes, J. M. (1963). Br. F. Cancer 17, 699.

Carnaghan, R. B. A. (1965). Nature, Lond. 208, 308.

Chang, S. B., Abdel Kader, M. M., Wick, E. L. \& Wogan, G. R. (1963). Science, N.Y. r42, I I91.

Culling, C. F. A. (1957). Handbook of Histopathological Technique. London: Butterworth.

De Iongh, H., Beerthuis, R. K., Vles, R. O., Barrett, C. B. \& Ord, W. O. (1962). Biochim biophys. Acta 65,548 .

Fiske, C. H. \& Subbarow, Y. (1925). 7. biol. Chem. 66, 375.

Hartley, R. D., Nesbitt, B. F. \& O'Kelly, J. (1963). Nature, Lond. 198, 1056.

Hoffman, W. S. (1937). F. biol, Chem. 120, 5 I.

Kelly, M. G., O'Gara, R. W., Adamson, R. H., Gadekar, M., Botkin, C. C., Reefe, W. H. \& Kerber, W. T. (1966). F. natn. Cancer Inst. 36, 323.

Kessler, G. \& Wolfman, M. (1964). Clin. Chem. 1o, 686.

Lancaster, M. C., Jenkins, F. P. \& Philp, J. McL. (1961). Nature, Lond. 192, ro95.

Loosemore, R. M. \& Harding, J. D. (196I). Vet. Rec. 73, 1362.

Loosemore, R. M. \& Markson, L. M. (1961). Vet. Rec. 73, 81 3 .

Malloy, H. T. \& Evelyn, K. A. (I937). F. biol. Chem. II9, 48I.

Marsh, W. H., Fingerhut, B. \& Kirsch, E. (I957). Am.. . clin. Path. 28, 681.

Nesbitt, B. F., O’Kelly, J., Sargeant, K. \& Sheridan, A. (1962). Nature, Lond. 195, ro62.

Powell, M. E. A. \& Smith, M. J. (1954). F. clin. Path. 7, 245.

Reitman, S. \& Frankel, S. (I957). Am. F. clin. Path. 28, 56.

Sargeant, K., O'Kelly, J., Carnaghan, R. B. A. \& Allcroft, R. (196r). Vet. Rec. 73, I219.

Sargeant, K., Sheridan, A., O'Kelly, J. \& Carnaghan, R. B. A. (196I). Nature, Lond. 192, rog6.

Tulpule, P. G., Madhavan, T. V. \& Gopalan, C. (1964). Lancet i, 962.

Weichselbaum, T. E. (1946). Am. F. clin. Path. 17, 40.

Van der Zijden, A. S. M., Koelensmid, W. A. A. B., Boldingh, J., Barrett, C. B., Ord, W. O. \& Philp, J. (1962). Nature, Lond. r95, I060.

Van Dorp, D. A., van der Zijden, A. S. M., Beerthuis, R. K., Sparreboom, S., Ord, W. O., de Jong, K. \& Keuning, R. (1963). Recl. Trav, chim. Pays-Bas, Belge. 82, 587.

Zall, D. M., Fisher, D. \& Garner, M. O. (1956). Analyt. Chem. 28, 1665. 